\title{
Winter Grazing in a Grass-Fed System: Effect of Stocking Density and Sequential Use of Autumn-Stockpiled Grassland on Performance of Yearling Steers
}

\author{
Domingo J. Mata-Padrino, E. E. D. Felton, W. B. Bryan, and D. P. Belesky \\ West Virginia University, Morgantown, WV 26506, USA \\ Correspondence should be addressed to Domingo J. Mata-Padrino; djmatapadrino@mail.wvu.edu
}

Received 27 September 2016; Revised 15 December 2016; Accepted 22 January 2017; Published 19 February 2017

Academic Editor: David Clay

Copyright (c) 2017 Domingo J. Mata-Padrino et al. This is an open access article distributed under the Creative Commons Attribution License, which permits unrestricted use, distribution, and reproduction in any medium, provided the original work is properly cited.

\begin{abstract}
Winter grazing can help reduce the need for purchased feeds in livestock production systems, when finishing cattle on pasture. Our objective was to evaluate the influence of stocking density and grazing stockpiled forage on performance of yearling steers during winter. Three grasslands were winter grazed for two years: I, naturalized pastureland, and II and III, sown and managed for hay production during the growing season but grazed in winter. Two stocking densities were used: low 7.41 and high 12.35 steers ha $^{-1}$. Herbage mass was estimated before and after each grazing event, and disappearance (consumption, weathering, and trampling) was the difference between both. Forage mass and residual differed by stocking density (SD), year (YR), and grazing interval (GI), and disappearance differed by YR and GI. Grass and dead constituents of botanical composition differed by YR and GI. No differences were found for legumes and forbs. CP differed by YR and GI, and NDF and ADF differed only by YR. Steer average daily gain was $0.15 \mathrm{~kg} \mathrm{~d}^{-1}$ in 2011 and $0.68 \mathrm{~kg} \mathrm{~d}^{-1}$ in 2012 and varied by YR and GI. Acceptable gains in 2012 may be a product of environmental conditions that influenced herbage mass and nutritive value during stockpile and animal behavior during winter.
\end{abstract}

\section{Introduction}

Sustaining livestock on pasture throughout the year in temperate regions is dictated by weather conditions within and among years. Herbage production during the growing season often is restricted by precipitation deficits even when day length and temperatures are favorable [1]. In autumn and winter, decreasing temperatures and photoperiods contribute to forage plant dormancy and, eventually, the cessation of active growth. In some instances, forage plants adapted to water deficit and high temperatures and forage capable of sustaining some growth at lower temperatures can be used to stabilize variation in herbage production. Since pastures throughout the Appalachian region comprise many different species of grasses, legumes, and forbs, some level of sustained productivity would be more likely when temperature and precipitation trends vary with climate variability [2]. In cooltemperate regions, this might mean that plants adapted to warm-season growing conditions would persist and extend the interval of active herbage production and thus grazing time in late autumn and winter. However, when pasture growth is less than that required to meet grazing animal needs, stored or purchased feeds must be provided [3]. In cool-temperate regions, winter typically is the time when stored feeds are used to sustain grazing livestock performance on pasture. Winter grazing may contribute to profitability of forage-based production systems by reducing the need for purchased or stored feeds.

Volesky et al. [4] noted that stockpiled forage should be grazed during late autumn and early winter (November and December) in the central US to take advantage of herbage quantity and nutritive value. Delaying herbage use beyond late autumn is likely to result in mass and nutritive value losses $[5,6]$. This occurs because of tissue damage caused by exposure to weather $[7,8]$. Susceptibility to weather-related damage may be a function of the species stockpiled [9].

Animal performance is influenced by interactions occurring among herbage mass, nutritive value, weather, and 
grazing behavior, such as selectivity among sward components, grazing time and location, and previous experience $[1,10]$. Recommendations for winter grazing often are based upon general knowledge about forage growth developed during the growing season for a given location. However, this approach may neglect changes in grazing animal behavior as herbage growth ceases with less favorable weather-related growing conditions. During winter, livestock may spend less time foraging over a large area and more time on a relatively smaller area of pasture [11]. This typically contrasts with longer periods of foraging that occur during milder weather conditions. Patton et al. [1] noted that grazing influenced the amount of herbage produced and that modest grazing intensity improved production over nongrazed areas. Wade and Carvalho [12] stated that, at an empirical level, animal responses to stocking methods and stocking density are now well known. However, livestock response to the interactions of weather, herbage mass, nutritive value, and grazing behavior is complex and not well understood.

Livestock production systems that include winter grazing as a component of pasture management must take into account season-long influences and interactions of livestock grazing activities with the forage resources available. Considerations include weather, location of winter feeding sites on the pasture, edaphic features, and pasture botanical composition during the stockpiling period. Short-term variations in production and chemical composition could be related to management and weather during the growing season [13], whereas long-term changes could be a product of management and environment interacting with time [1].

Mata-Padrino et al. [14] noted that when grasslands comprising different locally adapted forage species were grazed simultaneously, herbage quality declined more quickly on naturalized permanent grassland, while tall fescue dominant swards maintained herbage quality the longest and orchardgrass dominant swards were intermediate. To validate this observation, we grazed the grasslands in a sequence related to tolerance to late-season weather conditions for this experiment. Our objective was to determine whether average daily gain of steers and total gain per hectare were influenced by stocking density when using stockpiled herbage sequentially.

\section{Materials and Methods}

2.1. Site Conditions. The experiment was conducted at the West Virginia University Reedsville Experiment Farm, located in Preston County, WV $\left(39^{\circ} 30^{\prime} \mathrm{N}, 79^{\circ} 47^{\prime} \mathrm{W} ; 537 \mathrm{~m}\right.$ elevation), on the Appalachian High Plateau of the eastern US. Three grasslands grazed during winter from 2004 to 2009 were divided into 24 paddocks of 0.405 ha. The paddocks were grazed by 24 Bos taurus steers divided into two groups to create low 7.41 and high 12.35 steers ha ${ }^{-1}$ stocking densities (SD), each replicated three times. We created a sequential grazing scheme based on previously observed resilience of the grassland communities to winter conditions [14]. Each grassland represented one of three grazing intervals (GI) coincident with pasture type (Table 1 ). In order to maintain
TABLE 1: Sequence and schedule for winter grazing.

\begin{tabular}{lcccc}
\hline \multirow{2}{*}{ Year } & & \multicolumn{3}{c}{ Grazing interval } \\
& & I $^{\dagger}$ & II & III \\
\hline \multirow{2}{*}{2011} & In & Nov 2 & Nov 22 & Dec 16 \\
& Out & Nov 22 & Dec 16 & Jan 4 \\
2012 & In & Nov 12 & Nov 26 & Dec 18 \\
& Out & Nov 26 & Dec 18 & Jan 9 \\
\hline
\end{tabular}

${ }^{\dagger}$ I: naturalized permanent grazingland; II: orchardgrass cultivated pastureland; III: tall fescue cultivated pastureland.

the sequence based on grassland endurance to late autumnwinter conditions, the second grazing interval comprised twice the number of paddocks as the initial and final grazing interval.

The experiment on winter grazing of autumn-stockpiled herbage was conducted from August 2011 to January 2013 with herbage stockpiling beginning in August of each year and later grazed from early November until early January. Grasslands were defined as follows and will henceforth be referred to as I, naturalized permanent grazingland, and II and III, sown and managed primarily to hay production during the growing season but grazed during winter. The sequence began with grassland I, which consisted of a mixture of orchardgrass (Dactylis glomerata L.), velvet grass (Holcus lanatus L.), timothy (Phleum pratense L.), other grasses of lesser quality and presence in the sward, white clover (Trifolium repens L.), red clover (T. pratense L.), and forbs. Forbs included ground ivy (Glechoma hederacea L.), dandelion (Taraxacum officinale Weber ex F. H. Wigg.), dock (Rumex spp. L.), plantain (Plantago spp.), and horsenettle (Solanum carolinense L.), followed by grassland II that consisted mainly of orchardgrass, timothy, alfalfa (Medicago sativa L.), white and red clover, and forbs including Canada thistle (Cirsium arvense (L.) Scop.), bedstraw (Galium aparine L.), ground ivy, and dock and grassland III that consisted mainly of tall fescue (Schedonorus arundinaceus (Schreb.) Dumort.), orchardgrass, and white and red clover along with the forbs bedstraw, plantain, ragweed (Ambrosia artemisiifolia L.), and smartweed (Polygonum pensylvanicum L.).

Soil was sampled annually ( 0 to $5 \mathrm{~cm}$ depth) at 20 to 25 locations along a predetermined transect in each grassland for estimates of soil nutrient status. Lime (dolomitic) was applied to maintain $\mathrm{pH}$ above 5.8 and triple superphosphate and potassium chloride were applied to maintain soil available $\mathrm{P}$ and $\mathrm{K}$ above $65 \mathrm{~kg} \mathrm{ha}^{-1}$ and $195 \mathrm{~kg} \mathrm{ha}^{-1}$, respectively. Daily maximum and minimum temperatures and precipitation were recorded at the experiment site.

\subsection{Plant Measurements}

2.2.1. Forage Mass. Herbage mass was determined using the plate meter technique described by E. B. Rayburn and S. B. Rayburn [15] in each paddock within each grassland. Seventy-five sward height measurements were made in each paddock before and after grazing. Sampling sites were located by global satellite positioning at fixed intervals on four transects within each paddock. Means of all sampling sites within 
a given paddock provided an estimate of the sward height for each. The difference between forage mass determined before grazing and residual herbage mass after each grazing event was assumed to represent herbage disappearance. Disappearance comprises the herbage consumed by grazing animals as well as senesced, damaged, and detached leaves.

Sward height was converted to herbage mass using the following equation:

$$
\begin{aligned}
& \text { Forage mass }\left(\mathrm{kg} \mathrm{ha}^{-1}\right) \\
& \quad=266.15 \bullet \text { sward height }(\mathrm{cm})+265 .
\end{aligned}
$$

This equation was derived from data collected from each of the paddocks in each grassland unit from 2004 through 2009 [14].

2.2.2. Botanical Composition and Nutritive Value. Prior to grazing each paddock, 6 forage samples were collected for botanical composition and nutritive value analyses along the same transects used to estimate herbage mass. Samples were clipped to the soil surface within a $0.07 \mathrm{~m}^{2}$ quadrat. Samples collected were placed in paper bags and stored at $0^{\circ} \mathrm{C}$ until processed. Herbage samples were hand-sorted into grasses, legumes, forbs, and dead material. Grasses and forbs were separated further by species. Grasses included orchardgrass, tall fescue, timothy, velvet grass, and other grasses, which represented infrequently occurring sward components. Forbs included bedstraw, Canada thistle, ground ivy, dandelion, dock, horsenettle, smartweed, ragweed, plantain, and other ephemeral and infrequently occurring forbs. Individual species and total sampled area weights were determined and the percentage of each component of the sward was computed. Individual sward components were placed in paper bags and air-dried at $60^{\circ} \mathrm{C}$ in a forced-draft oven for $48 \mathrm{~h}$. Dry samples were weighed and then recombined by grassland. Two subsamples collected from each grassland were ground using a stainless steel Wiley mill (Model 4, A. H. Thomas, Philadelphia, PA) equipped with a $1 \mathrm{~mm}$ particle size screen. All nutritive analyses were performed in duplicate. Dry matter $\left(105^{\circ} \mathrm{C}\right)$, ash, and crude protein (CP) (Kjeldahl N $\times 6.25)$ were determined according to AOAC [16] procedures. Neutral detergent fiber (NDF), acid detergent fiber (ADF), and lignin were determined sequentially according to Van Soest et al. [17] using modifications outlined in the $\mathrm{ANKOM}^{\odot}$ fiber analysis procedure (ANKOM Technology, Macedon, NY).

2.3. Animal Measurements. Steers used during 2011-2012 were born and raised in Virginia, whereas those used in 2012-2013 were born and raised at the Reedsville farm where the experiment was conducted. Steers were assigned each year randomly among paddocks by weight and frame size at the start of the winter grazing. Animals were treated for internal and external parasites at the beginning of the winter grazing. Three grazing intervals were coincident with grazing grasslands I, II, and III in sequence. Animals were weighed at the start of each grazing interval until the conclusion of the experiment, providing a total of four live weight measurements per animal for each year. A uniform method for weighing livestock is critical when comparing livestock responses to treatment or conditions in both commercial and research settings [18]. We removed grazers from paddocks at $0700 \mathrm{~h}$ and then weighed the animals between 1000 and $1100 \mathrm{~h}$ for each weighing date. Animals were returned to paddocks at $1200 \mathrm{~h}$ on the same day. All animals were handled in the same manner at each weighing event to help minimize differences attributable to grazing behavior. Productivity per hectare was calculated each year, for treatment and for the complete grazing interval.

2.4. Statistical Analysis. Paddock was the experimental unit for grassland and animal measurements. All forage data were analyzed as a completely random design, replicated three times, using the PROC-MIXED procedure of SAS [19]. For grazing management and botanical composition data, the model included year, stocking density grazing interval, and their interactions. Analysis of nutritive value included year, grasslands, and their interaction in the model. In both analyses, a repeated measurement statement and the denominator degrees of freedom using the Kenward-Roger option were included. Average daily gain was calculated for each grazing interval and reported as season-long total gain. The model used to analyze ADG included year, stocking density, grazing interval, and their interactions, and a repeated measurement statement and the denominator degrees of freedom using the Kenward-Roger option were computed. Treatment least squares means were calculated and means compared using LSR when the $\mathrm{F}$ test for means was significant $(P<0.05)$. Initial weight each year was compared between stocking densities with one-way ANOVA using the PROC-MIXED procedure of SAS.

\section{Results and Discussion}

3.1. Weather Conditions. Precipitation and air temperature varied by month and year during the stockpile and winter grazing interval of the experiment years and when compared to location 30-year mean (Figures 1 and 2). Variable weather conditions would contribute to variations observed in herbage accumulation in late summer/early fall and in animal performance during the grazing period. Total precipitation was above normal throughout the duration of the experiment (2011-2012); however, it was less than the 30year mean in August and November 2012. Temperatures were similar to the 30-year mean and less than the long-term mean only in November 2012.

During stockpile, precipitation and air temperature have a significant influence on forage production and quality and could be more important determinants of sward composition, herbage mass, and nutritive value than management imposed during late summer and autumn $[1,6]$.

Winter grazing in grass-fed systems is highly dependent on weather [14]. Also, during winter grazing, temperatures and snow cover can affect grazing behavior and animal performance [20-22]. During winter-stocking period of 201112 , snow covered the grasslands for a few days. Nevertheless, 


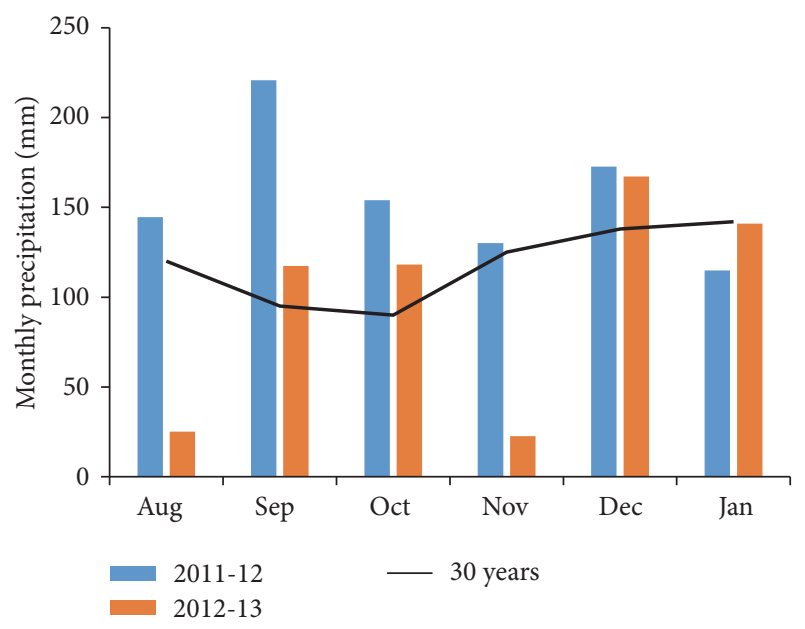

Figure 1: Monthly precipitation and 30-year mean values at Reedsville, WV.

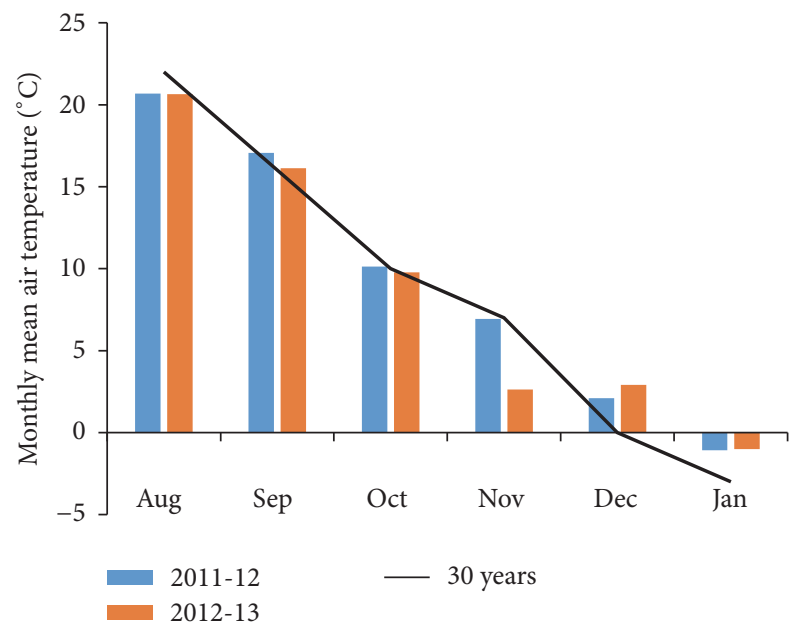

FIGURE 2: Monthly mean air temperature and 30-year mean values at Reedsville, WV.

in December 2012 and January 2013, snow covered the pasture for a longer period, which restricted grazer access to herbage.

3.2. Grassland Characterization. Riesterer et al. [23] proposed a schedule to use stockpiled grasslands in Wisconsin depending on species endurance. Similarly, our previously reported observations [14] suggested a sequence of use based on resistance to weathering. A thorough understanding of the pregraze pastures was needed to help explain any difference which may occur as a result of stocking density on average daily gain of yearling steers during winter.

3.2.1. Forage Mass. Stockpiled forage mass, determined prior to each winter grazing interval, averaged $2948 \mathrm{~kg} \mathrm{ha}^{-1}$ for the two-year experiment (Table 2). Stockpiled forage mass measure at the two stocking densities showed differences $(P=0.0155)$ attributable to weather and soil moisture variability during the stockpile. Year and grazing interval were also different (both $P<0.0001$ ), with the difference
TABLE 2: Forage mass, residual forage mass, and forage disappearance of each grassland for two years.

\begin{tabular}{ccccc}
\hline \multicolumn{2}{c}{ Year Grazing interval $^{\dagger}$} & Forage mass $^{\text {Residual }}$ & $\begin{array}{c}\text { Disappearance } \\
\mathrm{kg} \mathrm{ha}^{-1}\end{array}$ \\
\hline \multirow{2}{*}{2011} & I & $3900^{\mathrm{a}}$ & $1701^{\mathrm{b}}$ & $2199^{\mathrm{a}}$ \\
& II & $3164^{\mathrm{b}}$ & $1517^{\mathrm{c}}$ & $1647^{\mathrm{b}}$ \\
& III & $3257^{\mathrm{b}}$ & $1480^{\mathrm{c}}$ & $1777^{\mathrm{b}}$ \\
\hline \multirow{3}{*}{2012} & I & $2562^{\mathrm{c}}$ & $1848^{\mathrm{a}}$ & $714^{\mathrm{d}}$ \\
& II & $2141^{\mathrm{d}}$ & $1419^{\mathrm{d}}$ & $722^{\mathrm{d}}$ \\
& III & $2664^{\mathrm{c}}$ & $1592^{\mathrm{b}}$ & $1072^{\mathrm{c}}$ \\
\hline
\end{tabular}

Means in the same column followed by a different lowercase letter are different at the 0.05 probability level.

${ }^{\dagger}$ I: naturalized permanent grazingland; II: orchardgrass cultivated pastureland; III: tall fescue cultivated pastureland.

probably attributable to precipitation during stockpile and weathering during the winter grazing intervals (Table 4). Interactions were significant for YR * GI $(P<0.0001)$ and $\mathrm{SD} * \mathrm{YR}(P=0.0022)$. An explanation for these interactions may be the different way cold weather influenced the grasslands during each year and differences associated with pregraze herbage mass and stocking densities. Herbage production was lower for the same grasslands during winter of 2005-2009 when using strip-grazing management [14]. The increase in production obtained in this experiment may be explained by the use of a grazing sequence based on grassland that helped avoid the deterioration of herbage mass and quality resulting from late autumn and winter weather conditions. Prigge et al. [24] and Baker et al. [25] found similar forage production for orchardgrass during autumn at the WVU Reedsville Experiment Farm. Tall fescue mass determined in our experiment was less than that reported in North Carolina [26], but similar to the amounts obtained at Morgantown, West Virginia [6, 7], Wooster, Ohio [27], and Columbia, Missouri [28].

Volesky et al. [4] observed that orchardgrass was more susceptible than tall fescue to effects of snow compression and as a result would present relatively less herbage available for grazing. Collins and Balasko [6] found that herbage mass of stockpiled tall fescue declined from $2500 \mathrm{~kg} \mathrm{ha}^{-1}$ in December to $2250 \mathrm{~kg} \mathrm{ha}^{-1}$ by February, demonstrating possible loss attributable to leaf senescence or weathering. Disappearance averaged $2794 \mathrm{~kg} \mathrm{~d}^{-1}$ for the low stocking density and $2954 \mathrm{~kg} \mathrm{~d}^{-1}$ for the higher; performance showed that despite trampling and differences in pregrazing and residual forage mass the steers could remove similar amounts of forage in both stocking densities (Table 3).

Residual forage mass differed between treatments $(P<$ 0.0312 ); however, it is the resultant effect of using the residual herbage on pastures with greater stocking rate as a determinant to move animals to the next grassland. In addition, grazing interval $(P<0.0001)$ showed the effect of weathering as the season advances. Residual herbage was influenced by $\mathrm{YR} \times \mathrm{GI}(P=0.0011)$ and $\mathrm{YR} \times \mathrm{SD}(P=0.0008)$ interactions. Herbage disappearance differed by year and interacted with stocking density (both $P<0.0001$ ). Grazing interval 
TABLE 3: Forage mass, residual forage mass, and forage disappearance by stocking density for two years.

\begin{tabular}{lcccc}
\hline Year Stocking density & Forage mass & $\begin{array}{r}\text { Residual } \\
\mathrm{kg} \mathrm{ha}^{-1}\end{array}$ & Disappearance \\
\hline \multirow{2}{*}{2011} & Low SD & $3234^{\mathrm{a}}$ & $1661^{\mathrm{a}}$ & $1737^{\mathrm{a}}$ \\
& High SD & $3509^{\mathrm{b}}$ & $1447^{\mathrm{b}}$ & $1847^{\mathrm{a}}$ \\
\multirow{2}{*}{2012} & Low SD & $2355^{\mathrm{c}}$ & $1565^{\mathrm{c}}$ & $781^{\mathrm{b}}$ \\
& High SD & $2399^{\mathrm{c}}$ & $1574^{\mathrm{c}}$ & $834^{\mathrm{b}}$ \\
\hline
\end{tabular}

Means in the same column followed by a different lowercase letter are different at the 0.05 probability level.

${ }^{\dagger} \mathrm{SD}$ : stocking density. Low $\mathrm{SD}=7.41$ steers $\mathrm{ha}^{-1}$ and high $\mathrm{SD}=12.35$ steers $\mathrm{ha}^{-1}$.

TABLE 4: Analysis of variance of forage mass, residual herbage, forage disappearance, and forage use as a function of stocking density, grazing interval, year, and their interactions.

\begin{tabular}{lccc}
\hline Source of variation & Forage mass & $\begin{array}{c}\text { Residual } \\
P \text { value }\end{array}$ & Disappearance \\
\hline Stocking density (SD) & 0.0155 & 0.0312 & NS \\
Year $(Y R)$ & $<0.0001$ & 0.0623 & $<0.0001$ \\
Grazing interval (GI) & $<0.0001$ & $<0.0001$ & 0.0009 \\
SD $*$ YR & 0.0022 & 0.0008 & $<0.0001$ \\
YR $*$ GI & $<0.0001$ & 0.0011 & NS \\
SD $*$ GI & NS & NS & NS \\
SD $*$ YR $*$ GI & 0.0010 & 0.0175 & 0.0427
\end{tabular}

${ }^{\dagger} \mathrm{SD}$ : stocking density. Low $\mathrm{SD}=7.41$ steers ha ${ }^{-1}$ and high $\mathrm{SD}=12.35$ steers $\mathrm{ha}^{-1}$.

showed differences for herbage disappearance but did not differ between stocking densities (Table 4). Forage mass in this experiment was determined by canopy height; those measurements would be influenced by snow compression and trampling. Furthermore, the effects of weathering and animal impact would depend on stocking densities and sward components. Despite the influence of limiting factors, analyzing forage mass in winter grazing situations may help explain the balance between herbage consumption, sward decomposition, and subsequently animal performance.

3.2.2. Botanical Composition. Grass and forbs were influenced by year and grazing interval regardless of stocking density. All principal botanical components were influenced by year interacting with grazing interval (Table 5 ). Differences in endurance of grass species in each grazing interval and precipitation and temperature patterns during the two years that the experiment lasted may have contributed to this response, even with the different pattern of snow precipitation and time that snow was covering grassland both years. In 2011, grazing intervals II and III had much more dead material than grazing interval I and more than any interval in 2012 (Figure 3). Grass was the predominant component in 2011 in grazing interval I, a relatively wet and warmer year, and primarily was represented by "other grasses." Conversely, during 2012, cultivated cool-season grasses represented a greater proportion in the grass component (Figure 4), but again the botanical composition of naturalized grasslands
TABLE 5: Analysis of variance for main components of grassland botanical composition as a function of stocking density, grazing interval, year, and their interactions.

\begin{tabular}{lcccc}
\hline Source of variation & Grass & $\begin{array}{c}\text { Legume } \\
P \text { value }\end{array}$ & Forb & Dead \\
\hline Stocking density (SD) & NS & NS & NS & NS \\
Year (YR) & 0.0124 & NS & NS & $<0.0001$ \\
Grazing interval (GI) & 0.0425 & NS & NS & $<0.0001$ \\
SD $*$ YR & NS & NS & NS & NS \\
YR $*$ GI & $<0.0001$ & 0.0348 & 0.0089 & $<0.0001$ \\
SD $*$ GI & NS & NS & NS & NS \\
SD $*$ YR $*$ GI & NS & NS & NS & NS \\
\hline
\end{tabular}

grazed in interval I performed differently, with a decreasing grass proportion. Tall fescue was the most reduced cultivated cool-season grass during 2011. Proportion of other grasses and forbs along with higher air temperatures during stockpile and lower air temperatures in December 2011 may explain that reduction in tall fescue proportion and the patterns of senesced herbage observed during winter grazing in 20112012. Legume did not have a considerable contribution to the forage available for winter grazing. Legume level increased in 2012 compared with 2011, grazing interval II with the greatest amount of legume. Conversely, the legume proportion in grazing interval III, corresponding with tall fescue pasture, was less in 2012 compared with 2011. The interaction YR * GI for legume component could be explained by changes in the legume component. Hitz et al. (2000) reported also a reduction in legume proportion when associated with fescue in winter grazing. The greatest percentages of forbs occurred during December 2011 during grazing interval II, an orchardgrass dominant pasture, with bedstraw the dominant forb (Figure 5). Hobbs et al. [29] found that orchardgrass pastures had an encroachment of weeds estimated in the range of $12-20 \%$ that was similar to forb proportion in orchardgrass dominant pasture. In both years, tall fescue dominant pastures compared to other pastures had fewer forbs, which is consistent with published results for tall fescue pastures $[29,30]$. Bedstraw was the most prevalent forb noted during winter grazing in grazing intervals II and III and thrived during dry and relatively cooler conditions occurring during the stockpiling interval of late summer and autumn. Ground ivy was dominant in grazing interval I but was also more abundant in all pastures when warmer temperatures occurred during stockpiling in 2011-2012. Dandelion seemed to be present in greater amounts during the relatively colder stockpiling interval of the 2012-2013 season (Figure 5), regardless of grazing interval.

3.2.3. Chemical Composition. Crude protein (CP) concentration differed during the two years of the experiment $(P=0.0003)$ and also differed by grazing interval (Tables 6 and 7). In 2011, CP concentration differed little between grazing intervals, but in 2012 the CP during grazing interval I was less than the $\mathrm{CP}$ of subsequent intervals. Variations 
TABLE 6: Crude protein (CP), neutral detergent fiber (NDF), acid detergent fiber (ADF), and lignin of forage collected from each grassland during a period of two years.

\begin{tabular}{|c|c|c|c|c|c|}
\hline Year & Grazing interval associated with grassland ${ }^{\dagger}$ & \multicolumn{4}{|c|}{$\mathrm{g} \cdot \mathrm{kg}^{-1}$} \\
\hline \multirow{3}{*}{2011} & $\mathrm{I}$ & $138^{\mathrm{c}}$ & $572^{\mathrm{b}}$ & $300^{\mathrm{a}}$ & 47 \\
\hline & II & $146^{\mathrm{c}}$ & $545^{\mathrm{bc}}$ & $255^{\mathrm{b}}$ & 45 \\
\hline & III & $145^{\mathrm{bc}}$ & $619^{c d}$ & $281^{\mathrm{c}}$ & 62 \\
\hline \multirow{3}{*}{2012} & I & $138^{\mathrm{c}}$ & $575^{\mathrm{b}}$ & $296^{\mathrm{a}}$ & 46 \\
\hline & II & $190^{\mathrm{a}}$ & $510^{\mathrm{d}}$ & $243^{\mathrm{c}}$ & 58 \\
\hline & III & $152^{\mathrm{a}}$ & $613^{\mathrm{d}}$ & $284^{\mathrm{c}}$ & 64 \\
\hline
\end{tabular}

Means in the same column followed by a different lowercase letter are different at $P<0.05$.

${ }^{\dagger}$ I: naturalized permanent grazingland; II: orchardgrass cultivated pastureland; III: tall fescue cultivated pastureland.

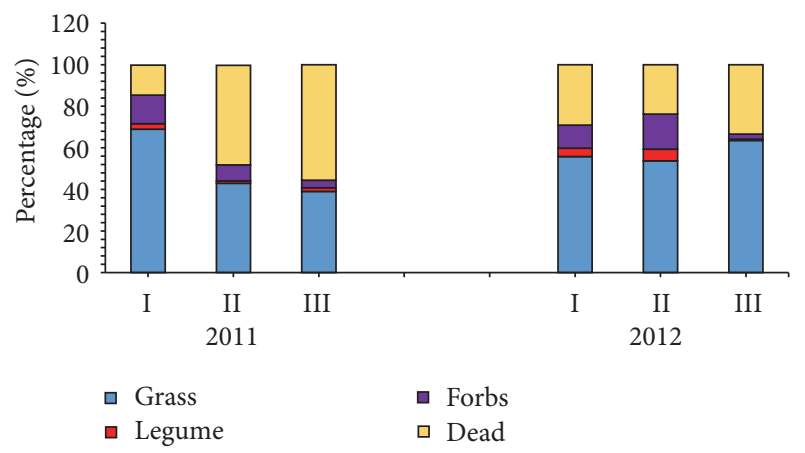

FIGURE 3: Botanical composition of grasslands used for winter grazing in three consecutive grazing intervals (I, II, and III) at Reedsville, WV. Grazing Interval: I = naturalized permanent grazingland, II = orchardgrass cultivated pastureland, and III = tall fescue cultivated pastureland.

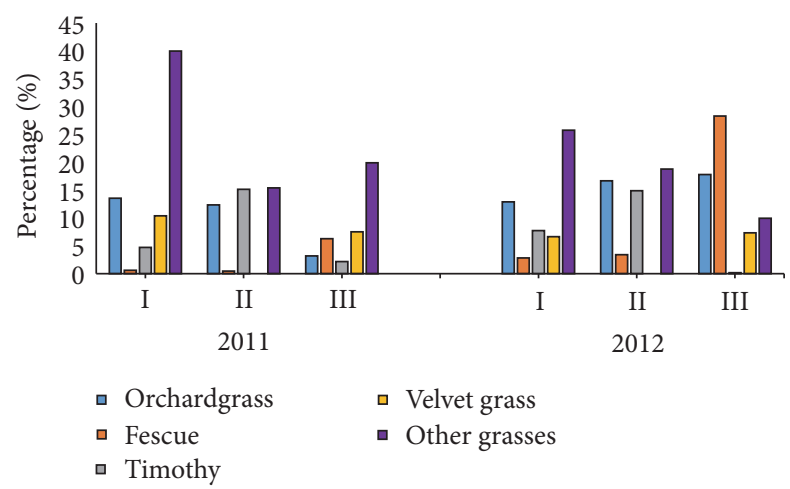

FIgURE 4: Proportion of dominant species in the grass component of grasslands used for winter grazing in three consecutive grazing intervals (I, II, and III) at Reedsville, WV. Grazing Interval: I = naturalized permanent grazingland, II = orchardgrass cultivated pastureland, and III = tall fescue cultivated pastureland.

in weather, $\mathrm{N}$ fertilization, and botanical composition contributed to these differences. Naturalized grassland had the lowest concentration of $\mathrm{CP}$ and the greatest proportion of other grasses. Concentrations of CP were the greatest in the cultivated grasslands, being greater in orchardgrass than in tall fescue dominant grasslands. This is consistent with other

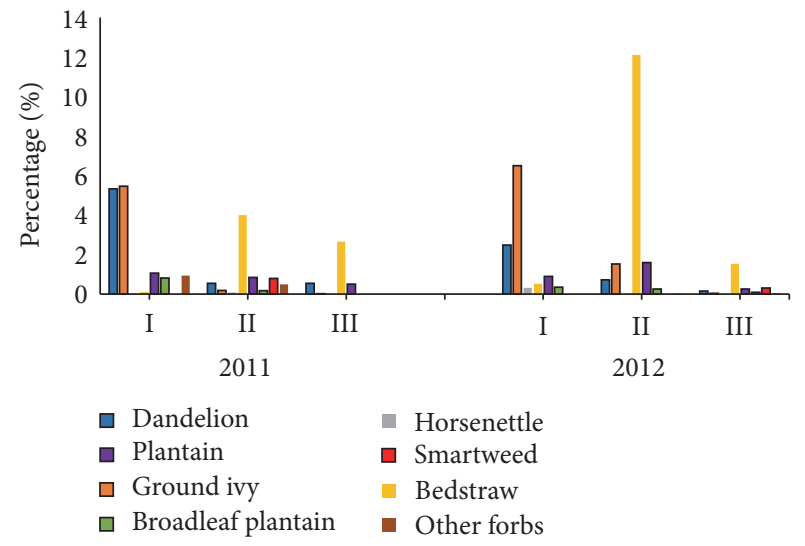

Figure 5: Proportion of dominant species in the forb component of grasslands used for winter grazing in three consecutive grazing intervals (I, II, and III) at Reedsville, WV. Grazing interval: I = naturalized permanent grazingland, II = orchardgrass cultivated pastureland, and III = tall fescue cultivated pastureland.

published work from the region $[14,25,31]$. Declining CP through fall and winter has been reported in some studies with fescue, orchardgrass, and other cool-season grasses, but fescue was consistently reported to be more resistant to the effects of winter weather conditions $[4,9,14,32$, $33]$. Collins and Balasko $[6,7]$ reported that, between midDecember and February, in vitro dry matter digestibility of tall fescue decreased significantly. Forage $\mathrm{CP}$ concentration in this experiment was greater than previously published data from this location [14, 25, 32]. Results suggest that sequential grazing of forage from most to least susceptible to deterioration related to winter weather conditions may have contributed to sustained herbage nutritive value. Time of sampling may also be a factor that contributes to differences in CP concentration between grazing intervals. Pérez-Prieto et al. [34] found that ryegrass grasslands performed similarly in winter and they related this to leafy conditions of the sward. Herbage ADF and NDF concentrations differed with year (Table 7), being higher in 2011. Grazing interval I maintained similar values both years but higher concentrations of dead material in the cultivated grasslands could be associated with higher proportions of dead material in 2011 [35]. They also 
TABLE 7: Analysis of variance for crude protein (CP), neutral detergent fiber (NDF), acid detergent fiber (ADF), and lignin as a function of grazing interval and year and their interaction.

\begin{tabular}{lcccc}
\hline Source of variation & CP & NDF & ADF & Lignin \\
& \multicolumn{4}{c}{$P$ value } \\
\hline Grazing interval (GI) & 0.0010 & NS & NS & NS \\
Year (YR) & 0.0003 & $<0.0001$ & 0.0004 & NS \\
YR * GI & 0.0007 & NS & NS & NS \\
\hline
\end{tabular}

TABLE 8: Average daily gain by grazing interval and treatment over two years.

\begin{tabular}{ccccccc}
\hline Year & $\begin{array}{c}\text { Grazing } \\
\text { interval }^{\dagger}\end{array}$ & $\begin{array}{c}\mathrm{ADG} \\
\left(\mathrm{kg} \mathrm{d}^{-1}\right)\end{array}$ & SEM $^{*}$ & $\begin{array}{c}\text { Stocking } \\
\text { density }\end{array}$ & $\begin{array}{c}\mathrm{ADG} \\
\left(\mathrm{kg} \mathrm{d}^{-1}\right)\end{array}$ & SEM $^{*}$ \\
\hline \multirow{2}{*}{2011} & I & 0.28 & & Low SD & 0.21 & 0.065 \\
& II & 0.44 & 0.085 & & & \\
& III & -0.26 & & High SD & 0.09 & 0.056 \\
& Total & 0.15 & 0.043 & & & \\
\hline \multirow{2}{*}{2012} & I & 2.00 & & Low SD & 0.73 & 0.065 \\
& II & 0.79 & 0.085 & & & \\
& III & -0.05 & & High SD & 0.62 & 0.056 \\
\hline
\end{tabular}

${ }^{\dagger}$ I: naturalized permanent grazingland; II: orchardgrass cultivated pastureland; III: tall fescue cultivated pastureland.

${ }^{\ddagger} \mathrm{SD}$ : stocking density. Low $\mathrm{SD}=7.41$ steers $\mathrm{ha}^{-1}$ and high $\mathrm{SD}=12.35$ steers $\mathrm{ha}^{-1}$.

${ }^{*}$ SEM: standard error.

found that orchardgrass fiber concentration was less than that of tall fescue. Volesky et al. [4] reported for orchardgrass NDF concentrations between 562 and $629 \mathrm{~g} \mathrm{~kg}^{-1}$, from December through January with slightly greater NDF for tall fescue during the same period. Meyer et al. [28] reported NDF and ADF concentrations similar to those presented here. Cultivated grasslands during the winter of 2012-2013 had chemical composition that was comparable to high quality forage in spring (e.g., high CP and low fiber). Lignin concentration was similar across all grasslands.

3.3. Animal Performance. Initial body weight of steers was not different between stocking densities and averaged $249 \mathrm{~kg}$ for both years: $241 \mathrm{~kg} \mathrm{~d}^{-1}$ in 2011 and $256 \mathrm{~kg} \mathrm{~d}^{-1}$ in 2012 . Steer performance differed with year $(P<0.0001)$ and tended to differ with stocking density $(P=0.0662)$. The group managed at 7.41 steers ha ${ }^{-1}$ (low density) consistently gained more steers on the higher density $\left(7.41\right.$ steers ha $^{-1}$ ) and there was no stocking density by year interaction (Tables 8 and 9). Paddocks stocked at the lower density for the same length of time led consistently to greater residual herbage mass; however, no differences for forage use were observed between the two stocking densities $(P=0.6048)$. Differences attributable to year may arise from the influence of weather on animal behavior and forage botanical and chemical composition. Winter 2011-2012 was slightly warmer with minimal snow cover of short duration (one day in December 2011
TABLE 9: Analysis of variance for average daily gain by stocking density, grazing interval, year, and their interactions.

\begin{tabular}{lc}
\hline Source of variation & $P$ value \\
\hline Stocking density $(\mathrm{SD})$ & 0.0662 \\
Year $(\mathrm{YR})$ & $<0.0001$ \\
Grazing interval $(\mathrm{GI})$ & $<0.0001$ \\
$\mathrm{SD} * \mathrm{YR}$ & $\mathrm{NS}$ \\
$\mathrm{YR} * \mathrm{GI}$ & $<0.0001$ \\
$\mathrm{SD} * \mathrm{GI}$ & $\mathrm{NS}$ \\
$\mathrm{SD} * \mathrm{YR} * \mathrm{GI}$ & $\mathrm{NS}$ \\
\hline
\end{tabular}

and two days in January 2012) during grazing interval III while tall fescue was grazed. Snow covered grasslands for short intervals during December 2012 during grazing interval II. Pasture was virtually continuously snow-covered during grazing interval III in late December and early January of 2013. Dunn et al. [21] suggested that grazing experience during winter influences foraging behavior. We observed that steers tended to graze more intensively in a limited area when temperatures were low or snow cover occurred, which was also observed by Krysl and Hess [22]. Wade and Carvalho [12] concluded that an inverse relationship between herbage intake and animal performance is a function of stocking density, where higher densities contribute to decreased available herbage per animal. In winter, that relationship may have a stronger impact as the animal grazing behavior changes. Botanical composition of pastures to be winter-grazed is usually determined at the end of the stockpile; however, changes in the short term may influence herbage quality and animal winter grazing behavior could affect overall performance [20, 21].

Animal productivity $\left(\mathrm{kg} \mathrm{ha}^{-1}\right)$ was much higher for winter grazing in 2012-2013 than in 2011-2012 (Figure 6). In addition, the lower stocking rate led to more gain per hectare in 2011-2012; however, in 2012-2013, it was the higher stocking rate that produced the most animal gain per hectare. This response might be explained by the influence of weather on forage quality and on animal behavior. In 2011-2012, forage mass, disappearance, and forage use were higher than in 20122013. However, forage quality was compromised in 2011-2012 by greater amounts of dead material, especially for grasslands used during grazing intervals II and III.

The results for productivity show that the effect of stocking density was the opposite in 2011-2012 of what it was in 2012-2013. In spite of lower forage mass and utilization, steers foraged more effectively in 2012-2013 under drier and cooler conditions, with more snow cover.

\section{Conclusions}

Our results support the conclusion that performance targets for ADG during winter grazing must consider environmental conditions during the grazing periods and the influence of weather during the late summer-autumn stockpile interval on forage quantity and quality available for winter grazing. However, it would be required to consider as well the influence of 


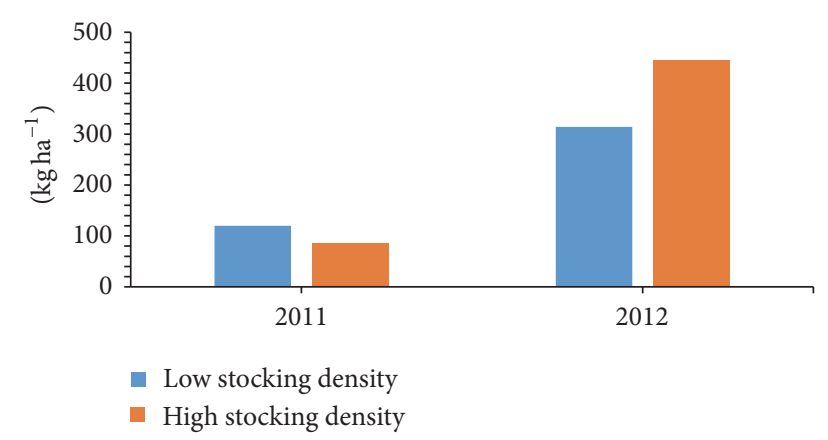

FIGURE 6: Productivity $\left(\mathrm{kg} \mathrm{ha}^{-1}\right)$ by stocking density, during winter grazing over two years.

SD on steer ADG. Our outcomes revealed a favorable trend by decreasing SD during winter grazing. The proportion of senesced herbage as a fraction of sward botanical composition during winter is related to weather conditions during the stockpile interval. Weather also influenced animal grazing behavior during winter grazing and subsequently influenced animal performance and appeared to supersede aspects of management, such as grassland composition and stocking rate. Grassland responses were not influenced by stocking densities which implies that productivity per unit of land area during winter depended upon forage quality and the source of grazing animals.

\section{Competing Interests}

The authors declare that they have no competing interests.

\section{Acknowledgments}

The authors thank Rodney Kiser and the WVU Reedsville farm personnel for their help with site management, livestock handling, and field data collection and Eric Nestor and Kara Haught for conducting herbage nutritive value chemical analyses. Funding for this research was provided by the "Economic Pasture-Based Beef Systems for Appalachia” USDAARS (1932-21630-002-00D), Beaver, WV, specific cooperative agreement partnership with West Virginia University, Virginia Tech, and Clemson University.

\section{References}

[1] B. D. Patton, X. Dong, P. E. Nyren, and A. Nyren, "Effects of grazing intensity, precipitation, and temperature on forage production," Rangeland Ecology \& Management, vol. 60, no. 6, pp. 656-665, 2007.

[2] D. P. Belesky and D. P. Malinowski, "Grassland communities in the USA and expected trends associated with climate change," Acta Agrobotanica, vol. 69, no. 2, article 1673, 2016.

[3] J. P. Flores and B. Tracy, "Impacts of winter hay feeding on pasture soils and plants," Agriculture, Ecosystems and Environment, vol. 149, pp. 30-36, 2012.

[4] J. D. Volesky, B. E. Anderson, and M. C. Stockton, "Species and stockpile initiation date effects on yield and nutritive value of irrigated cool-season grasses," Agronomy Journal, vol. 100, no. 4, pp. 931-937, 2008.

[5] E. B. Rayburn, R. E. Blaser, and D. D. Wolf, "Winter tall fescue yield and quality with different accumulation periods and $\mathrm{n}$ rates," Agronomy Journal, vol. 71, no. 6, pp. 959-963, 1979.

[6] M. Collins and J. A. Balasko, "Effects of N fertilization and cutting schedules on stockpiled tall fescue. I. Forage yield," Agronomy Journal, vol. 73, no. 5, pp. 803-807, 1981.

[7] M. Collins and J. A. Balasko, "Effects of N fertilization and cutting schedules on stockpiled tall fescue. II. Forage quality," Agronomy Journal, vol. 73, no. 5, pp. 821-826, 1981.

[8] J. C. Burns and D. S. Chamblee, "Summer accumulation of tall fescue at low elevations in the humid Piedmont: II. Fall and winter changes in nutritive value," Agronomy Journal, vol. 92, no. 2, pp. 217-224, 2000.

[9] V. S. Baron, A. C. Dick, M. Bjorge, and G. Lastiwka, "Stockpiling potential of perennial forage species adapted to the Canadian western Prairie Parkland," Agronomy Journal, vol. 96, no. 6, pp. 1545-1552, 2004.

[10] J. Hodgson, J. M. Rodriguez Capriles, and J. S. Fenlon, "The influence of sward characteristics on the herbage intake of grazing calves," The Journal of Agricultural Science, vol. 89, no. 3, pp. 743-750, 1977.

[11] J. C. Malechek and B. M. Smith, "Behavior of range cows in response to winter weather," Journal of Range Management, vol. 29, no. 1, pp. 9-12, 1976.

[12] M. H. Wade and P. C. F. Carvalho, "Defoliation patterns and herbage intake on pastures," in Grassland Ecophysiology and Grazing Ecology, G. Lemaire, J. Hodgson, A. Moraes, C. Nabinger, and P. C. F. Carvalho, Eds., pp. 233-248, CAB International, New York, NY, USA, 2000.

[13] M. H. Poore and M. E. Drewnoski, "Review: utilization of stockpiled tall fescue in winter grazing systems for beef cattle," Professional Animal Scientist, vol. 26, no. 2, pp. 142-149, 2010.

[14] D. Mata-Padrino, E. Felton, and W. B. Bryan, "Winter management of yearling steers in a grass-fed beef production system," Agronomy Journal, vol. 107, no. 3, pp. 1048-1054, 2015.

[15] E. B. Rayburn and S. B. Rayburn, "A standardized plate meter for estimating pasture mass in on-farm research trials," Agronomy Journal, vol. 90, no. 2, pp. 238-241, 1998.

[16] Association of Official Analytical Chemists, Official Methods of Analysis, Association of Official Analytical Chemists, Arlington, Va, USA, 17th edition, 2002.

[17] P. J. Van Soest, J. B. Robertson, and B. A. Lewis, "Methods for dietary fiber, neutral detergent fiber, and nonstarch polysaccharides in relation to animal nutrition," Journal of Dairy Science, vol. 74, no. 10, pp. 3583-3597, 1991.

[18] A. K. Watson, B. L. Nuttelman, T. J. Klopfenstein, L. W. Lomas, and G. E. Erickson, "Impacts of a limit-feeding procedure on variation and accuracy of cattle weights," Journal of Animal Science, vol. 91, no. 11, pp. 5507-5517, 2013.

[19] R. C. Littell, G. A. Milliken, W. W. Stroup, and R. D. Wolfinger, SAS Systems for Mixed Models, SAS Institute Inc., Cary, NC, USA, 1996.

[20] S. K. Beverlin, K. M. Havstad, E. L. Ayers, and M. K. Petersen, "Forage intake responses to winter cold exposure of freeranging beef cows," Applied Animal Behaviour Science, vol. 23, no. 1-2, pp. 75-85, 1989.

[21] R. W. Dunn, K. M. Havstad, and E. L. Ayers, "Grazing behavior responses of rangeland beef cows to winter ambient temperatures and age," Applied Animal Behaviour Science, vol. 21, no. 3, pp. 201-207, 1988. 
[22] L. J. Krysl and B. W. Hess, "Influence of supplementation on behavior of grazing cattle," Journal of Animal Science, vol. 71, no. 9, pp. 2546-2555, 1993.

[23] J. L. Riesterer, D. J. Undersander, M. D. Casler, and D. K. Combs, "Forage yield of stockpiled perennial grasses in the upper midwest USA," Agronomy Journal, vol. 92, no. 4, pp. 740$747,2000$.

[24] E. C. Prigge, W. B. Bryan, and E. S. Goldman-Innis, "Earlyand late-season grazing of orchardgrass and fescue hayfields overseeded with red clover," Agronomy Journal, vol. 91, no. 4, pp. 690-696, 1999.

[25] M. J. Baker, E. C. Prigge, and W. B. Bryan, "Herbage production from hay fields grazed by cattle in fall and spring," Journal of Production Agriculture, vol. 1, no. 3, pp. 275-279, 1988.

[26] M. H. Poore, M. E. Scott, and J. T. Green Jr., "Performance of beef heifers grazing stockpiled fescue as influenced by supplemental whole cottonseed," Journal of Animal Science, vol. 84, no. 6, pp. 1613-1625, 2006.

[27] J. P. Schoonmaker, S. C. Loerch, J. E. Rossi, and M. L. Borger, "Stockpiled forage or limit-fed corn as alternatives to hay for gestating and lactating beef cows," Journal of Animal Science, vol. 81, no. 5, pp. 1099-1105, 2003.

[28] A. M. Meyer, M. S. Kerley, R. L. Kallenbach, and T. L. Perkins, "Comparison of grazing stockpiled tall fescue versus feeding hay with or without supplementation for gestating and lactating beef cows during winter," Professional Animal Scientist, vol. 25, no. 4, pp. 449-458, 2009.

[29] C. S. Hobbs, T. W. Jr. High, and I. Jr. Dyer, "Orchardgrass and fescue pastures for producing yearling slaughter steers," in University of Tennessee Agricultural Experiment Station Bulletin, University of Tennessee Agricultural Experiment Station, Oak Ridge, Tenn, USA, 1965.

[30] K. Saikkonen, K. Ruokolainen, O. Huitu et al., "Fungal endophytes help prevent weed invasions," Agriculture, Ecosystems and Environment, vol. 165, pp. 1-5, 2013.

[31] K. A. Archer and A. M. Decker, "Autumn-accumulated tall fescue and orchardgrass. I. growth and quality as influenced by nitrogen and soil temperature," Agronomy Journal, vol. 69, no. 4, pp. 601-605, 1977.

[32] J. A. Balasko, "Effects of N, P, and K fertilization on yield and quality of tall fescue forage in winter," Agronomy Journal, vol. 69, no. 3, pp. 425-428, 1977.

[33] W. R. Ocumpaugh and A. G. Matches, "Autumn-winter yield and quality of tall fescue," Agronomy Journal, vol. 69, no. 4, pp. 639-643, 1977.

[34] L. A. Pérez-Prieto, J. L. Peyraud, and R. Delagarde, "Pasture intake, milk production and grazing behaviour of dairy cows grazing low-mass pastures at three daily allowances in winter," Livestock Science, vol. 137, no. 1-3, pp. 151-160, 2011.

[35] K. A. Archer and A. M. Decker, "Autumn-accumulated tall fescue and orchardgrass. ii. effects of leaf death on fiber components and quality parameters," Agronomy Journal, vol. 69, no. 4, pp. 605-609, 1977. 


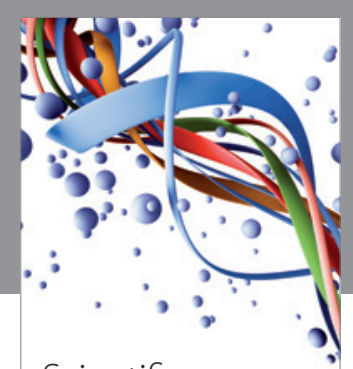

Scientifica
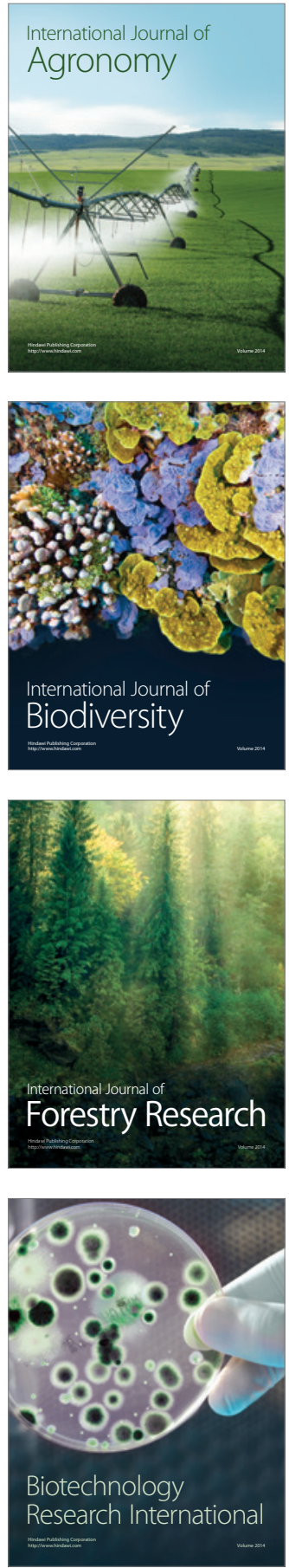
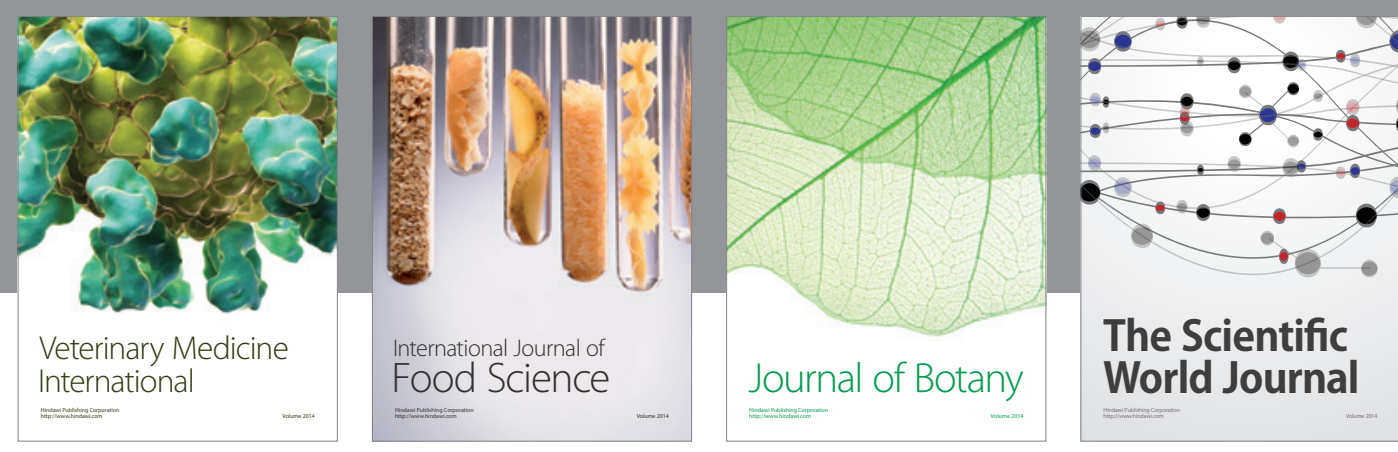

The Scientific

\section{World Journal}

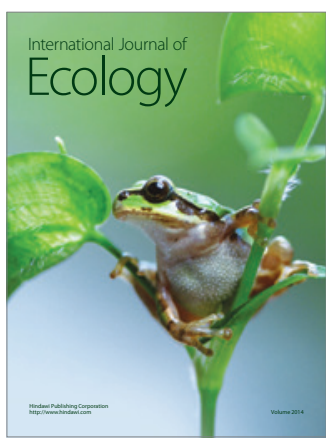

\section{Hindawi}

Submit your manuscripts at

https://www.hindawi.com
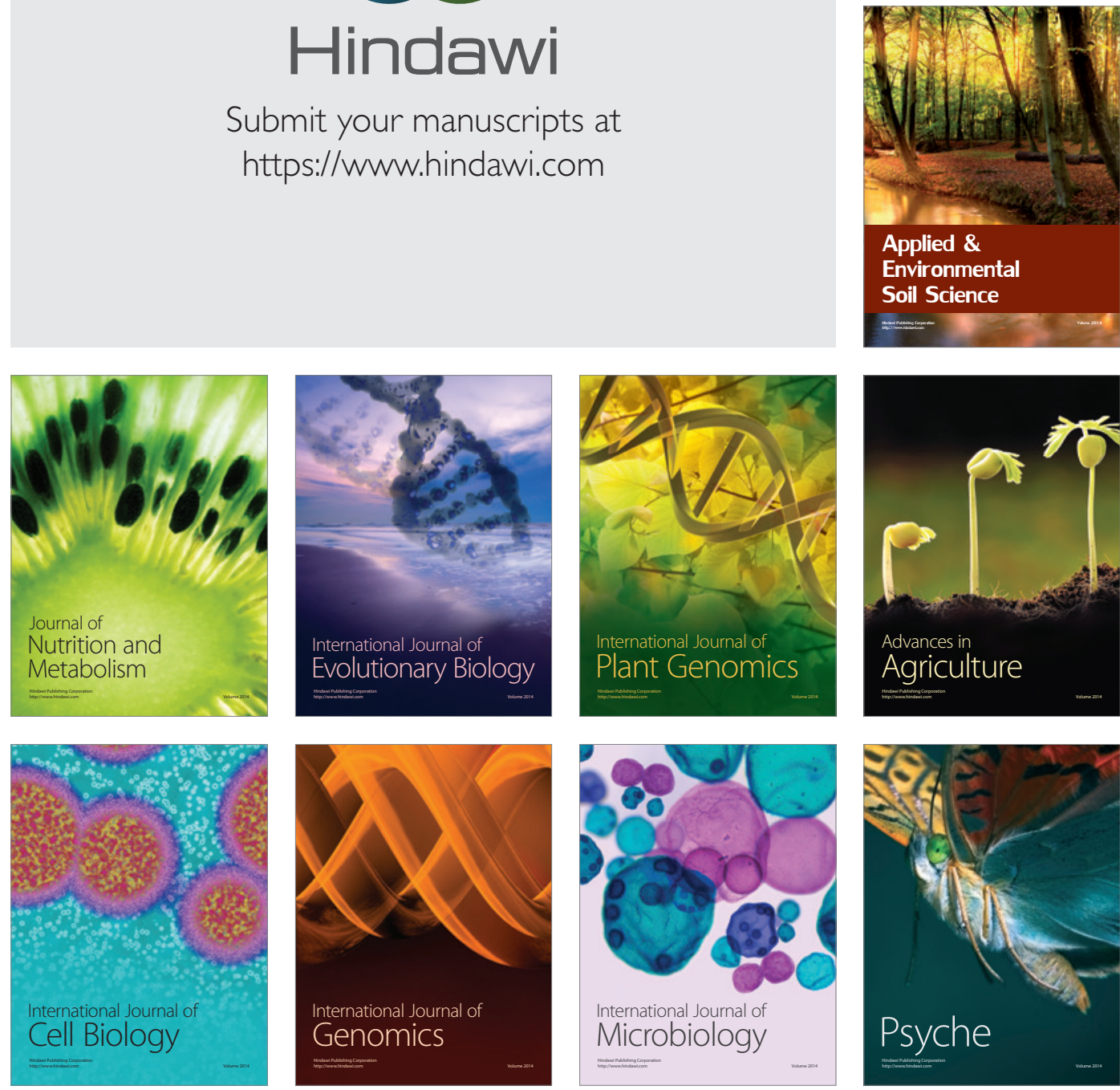
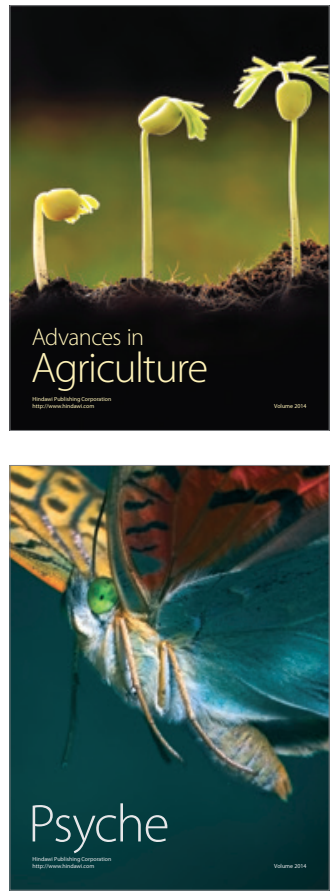